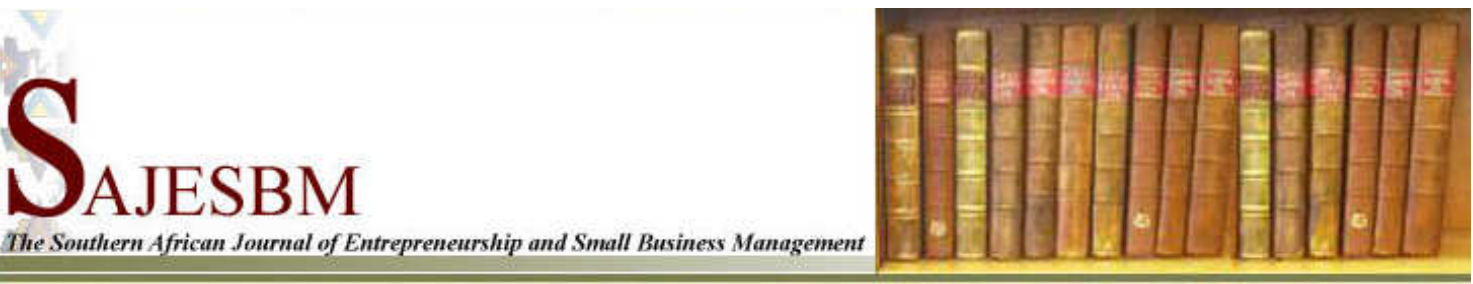

\title{
The influence of family and non-family stakeholders on family business success*
}

\author{
Shelley Farrington ${ }^{\star \star}$ and Elmarie Venter \\ Department of Business Management, Nelson Mandela Metropolitan University \\ PO Box 77 000, NMMU South Campus, \\ Port Elizabeth 6031, Republic of South Africa \\ Tel: +27-41-5042203; Fax: +27-41-5832644 \\ Shelley.Farrington@nmmu.ac.za \\ Elmarie.Venter@nmmu.ac.za
}

Christo Boshoff

Department of Business Management, Stellenbosch University

Private Bag X1, Matieland, 7602

Tel: +27-21-8082735; Fax: +27-41-8082226

cboshoff@sun.ac.za

* This paper is based upon work financially supported by the National Research Foundation of South Africa.

** To whom correspondence should be addressed.

\begin{abstract}
The greatest threats to the growth, success and survival of a family business are primarily issues related to family relationships. The involvement of non-family members has also shown to present many threats as well as opportunities for the family business. Because of the increasing number of sibling teams among family businesses this article focuses on the impact of family and non-family members' involvement on the success of sibling-owned family businesses. Key stakeholders identified as influencing a Sibling Partnership are parents, non-active sibling shareholders, spouses, and non-family members. The primary objectives of this article are thus to evaluate the impact of the stakeholders identified on the
\end{abstract}


success of a Sibling Partnership, by subjecting these relationships to empirical testing, and making recommendations to successfully manage relationships in family businesses.

A structured questionnaire was made available to 1323 sibling partner respondents. The respondents were identified by means of a convenience snowball sampling technique, and the data collected from 371 usable questionnaires was subjected to various statistical analyses.

The empirical findings of this study show that both past and present Parental involvement, as well as the involvement of Other family members and Non-family employees in the sibling-owned family businesses, significantly impact on its success.

Keywords and Phrases: Family business, Sibling Partnership, family team, family relationships, spouses, non-active shareholders, stakeholders. 


\section{INTRODUCTION AND PROBLEM STATEMENT}

Most family business researchers and practitioners would probably agree that family businesses derive their special nature from the influence of family on business (Hall \& Nordqvist, 2008). This being said, the greatest threats to the growth, success and survival of a family business are primarily issues related to family relationships (Goldberg, 1996; Mount, 1996; Royer, Simons, Boyd \& Rafferty, 2008; Ward, 1997; Ward, 2004). According to Molly, Laveren and Deloof (2010), it is from conflict laden family relationships that many family business problems originate. Interpersonal dynamics among family business members have, for example, been identified as a critical factor in the low number of successful multi-generational transfers among such businesses (Friedman, 1991; Kepner, 1991; Rodriguez, Hildreth \& Mancuso, 1999).

Family members often act out their intense personal and interpersonal issues in the family's business (Rodriguez et al., 1999). This overflow of family conflicts into the business, as well as coalition politics among family members, are key problems in family businesses (Kets de Vries, 1993). Running the family business is often more about managing family relationships than managing any other aspect of the business (Mount, 1996; Ward, 2004; Zbar, 2004).

Various types of family teams are increasingly drawing the attention of researchers and authors in the field of family business, particularly copreneurships (Eybers, 2010; Rutherford, Muse \& Oswald, 2006; Stewart-Gross \& Gross, 2007; Venter, Farrington \& Boshoff, 2009) and Sibling Partnerships (Farrington, 2010; Nelton, 1996; Ward, 2004). According to Aronoff, Astrachan, Mendosa and Ward (1997), Jimenez (2009), as well as Ward (2004), an increasing number of family businesses are being passed on during the succession process to teams of siblings, or adopting Sibling Partnerships as an ownership structure. Taking cognisance of this increase, more research attention should be directed towards these particular family business teams. By focussing on the influence of family and non-family members' involvement on the success of sibling teams in family businesses, this article and the ensuing empirical investigation respond to this gap in current family business research.

This article focuses on how family and non-family members, namely parents, spouses and non-active sibling shareholders, as well as non-family members, influence the ability of siblings in a Sibling Partnership to work together. As such, the purpose is to establish the impact of their involvement in the business and the relationship between the siblings, on the success of sibling-owned family businesses. The primary objectives of this article are to evaluate the impact of the involvement of these stakeholders on the success of a Sibling Partnership, by 
subjecting these relationships to empirical testing and making recommendations to successfully manage relationships in family businesses.

For the purpose of this article, the concepts "Sibling Partnership" and "sibling team" are used interchangeably and synonymously, and refer to a family business where at least two brothers and/or sisters, with a familial bond, are actively involved in the management and/or decision-making of the business, and exercise considerable influence over its strategic direction.

\section{KEY STAKEHOLDER RELATIONSHIPS IMPACTING ON SIBLING PARTNER- SHIPS}

Traditional input-output models of economic activity propose that businesses convert the inputs of investors, employees, and suppliers into usable outputs, which are then sold to customers and consequently result in capital benefits for the business. According to this model, businesses only address the needs and wishes of those four key parties, namely investors, employees, suppliers, and customers. Stakeholder theory, on the other hand, recognises that there are also other parties that are important to the successful functioning of a business (Stakeholder Theory, 2006). Instrumental approaches towards stakeholder theory hold that to maximise shareholder value over an uncertain time-frame, managers ought to pay attention to key stakeholder relationships. Firms have a stake in the behaviour of their stakeholders, and attention to stakeholder issues may help a firm to avoid decisions that might prompt stakeholders to undercut or thwart the firm's objectives (Strategic stakeholder management, 1999).

Stakeholder theory clearly has important implications for family businesses. Paying attention to both family and non-family stakeholder issues and relationships may help sibling partners avoid decisions that might prompt stakeholders to sabotage the partnership.

In addition to having the same stakeholders as other non-family businesses, key stakeholders to Sibling Partnerships are: family members, those having an investment in the business, such as parents (Lansberg, 1999; Ward, 2004); nonactive shareholders (Aronoff et al., 1997; Gersick, Davis, McCollom Hampton \& Lansberg, 1997); and those that do not have an investment in the business, such as retired owners and spouses (Aronoff et al., 1997; Fishman, 2009; Gersick et al., 1997; Lansberg, 1999; Schiff Estess, 1999). In addition, Poza, Alfred and Maheshwari (1997) regard both family and non-family employees as stakeholders in the family business. Sundaramurthy (2008) asserts that it is vital for family and nonfamily members to work together if the family business is to succeed and grow. Not only do the actions of these stakeholders influence the success of a Sibling 
Partnership, but the success or failure of the Sibling Partnership may also have important emotional and financial ramifications for them.

The family and non-family member stakeholders included in this study (see Figure 1) are justified by a sufficiency of theory in the family business literature, and claims are not made that the model has an exhaustive coverage of every possible relationship influencing the effectiveness of a Sibling Partnership.

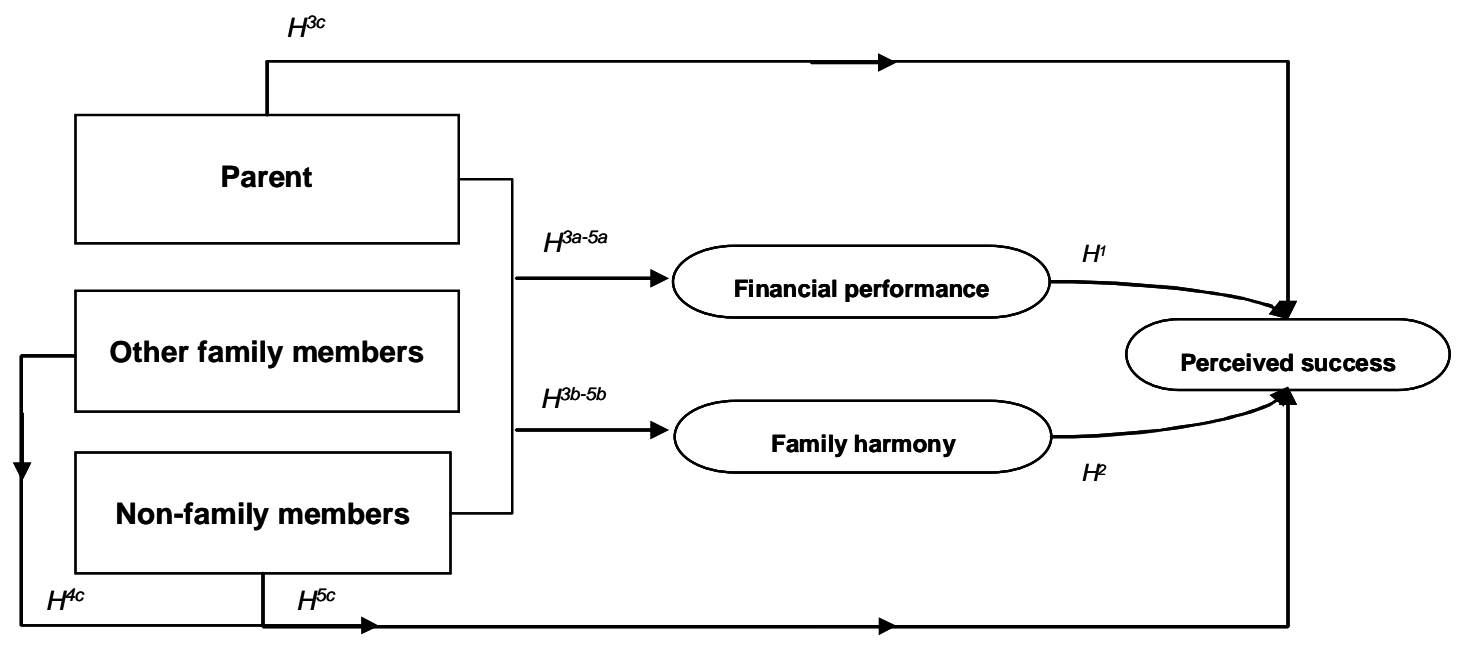

Figure 1 Family and non-family members influencing the Perceived success of Sibling Partnerships

In Figure 1 (the hypothesised model) the various family and non-family members identified as impacting the success of a Sibling Partnership are depicted, namely Parental involvement, as well as the involvement of Other family members and Nonfamily employees. Effectiveness or success in this study is measured using three variables: the dependent variable Perceived success; and two intervening variables, namely Financial performance and Family harmony. As such, the model proposes that both the perceived Financial performance of the business and the level of Family harmony that exists within the family business positively influence Perceived success.

\section{DEPENDENT AND INTERVENING VARIABLES}

As illustrated in Figure 1, the dependent variable used in this study is the Perceived success of a Sibling Partnership, which is defined as the degree to which the siblings find their ongoing involvement in the Sibling Partnership to be satisfying. Organisational effectiveness has been described as the ability of an organisation to satisfy the expectations of its strategic constituents. Given this description, it is clear that satisfying ones stakeholders plays a vital role in establishing success (Zellweger 
\& Nason, 2008). The satisfaction of family members involved in a family business is commonly associated with success in family business research (Distelberg \& Sorenson, 2009; Handler, 1991; Ivancevich, Konopaske \& Matteson, 2005; Sharma, 2004; Venter, 200; Zellweger \& Nason, 2008). Team-member satisfaction, as a measure of team effectiveness, has also been used in a number of studies assessing team effectiveness in organisations (e.g. Campion, Medsker \& Higgs, 1993; Campion, Papper \& Medsker, 1996; Doolen, Hacker \& Van Aken, 2006; Howard, Foster \& Shannon, 2005). In addition to the team members' satisfaction with the team experience, Kreitner and Kinicki (1995) suggest that the team members' willingness to continue contributing to the team effort is also a measure of team effectiveness.

Several authors have made use of business performance (financial and growth) as a measure of success to distinguish between successful and unsuccessful successions (Flören, 2002; Venter, 2003), successors (Goldberg, 1996), family businesses (Casillas, Moreno, Barbero, 2010; Distelberg \& Sorenson, 2009; Sharma, 2004; Ward, 2004) and even teams in general (Ivancevich et al., 2005; Northouse, 2004). According to Zellweger and Nason (2008:206), growths in sales and in employees, as well as profitability are examples of performance outcomes that satisfy the demands of stakeholders. Adendorff (2004) reports a positive relationship between profitability and the ability to satisfy stakeholders' interests. Similarly, Venter (2003) finds a positive relationship between the financial security of the owner-manager and the business, and the satisfaction with the succession process. Both anecdotal (Flören, 2002; Sharma, 2004; Ward, 2004) and empirical evidence (Santiago, 2000; Venter, 2003) suggests that harmonious relationships between family members are important for successful successions and successful family businesses. Zellweger and Nason (2008) assert that family harmony, trustful relations, cohesion and a sense of belonging are performance outcomes that satisfy the demands of family stakeholders.

In a family business characterised by disharmonious family relationships and poor financial performance, it is highly unlikely that family members involved will find their involvement to be satisfying, let alone want to continue being involved. Consequently, in addition to direct effects, the hypothesised model (Figure 1) implies that Financial performance and Family harmony act as intervening variables between the independent variables and the dependent variable Perceived success. For the purpose of this study Financial performance refers to positive trends of growth in number of employees and profit, as well as increasing revenue experienced by the Sibling Partnership. Family harmony, on the other hand, is defined as mutual relationships among family members, which are characterised by closeness, caring and support, appreciation of each other, and concern for each 
other's welfare. Against this background, the following hypotheses have been formulated:

$H^{1}$ : There is a positive relationship between the perceived Financial performance of the Sibling Partnership and the Perceived success of the Sibling Partnership.

$H^{2}$ : $\quad$ There is a positive relationship between the level of Family harmony existing in the Sibling Partnership and the Perceived success of the Sibling Partnership.

\section{INDEPENDENT VARIABLES}

Numerous researchers (e.g. Dyer, 1986; Ward, 1987; Lee, 2006; Lumpkin, Martin \& Vaughn, 2008) have focused their attention on the impact of family relationships on family businesses. Three key groups of family members are identified as influencing a Sibling Partnership, namely the parents, the non-active sibling shareholders, and the spouses (Aronoff et al., 1997; Gersick et al., 1997; Handler, 1991; Maas, Van der Merwe \& Venter, 2005). Focusing on these three key family relationships does not imply that other people or relationships with friends, children and/or colleagues, do not impact the ability of siblings to work together. For the purpose of this study, and based on the literature and anecdotal evidence, these other relationships are either not considered as family-based (for example friends and colleagues) or are not considered as key at this stage in influencing the ability of siblings to work together (for example children).

In addition to family members, outsiders or non-family members are an important stakeholder group, and often make a vital contribution to the success and growth of the family business (Fishmen, 2009; Sharma, 2004; Ward, 2004; Zellweger \& Nason, 2008). Relationships with non-family members include relationships with non-family employees, the directors of the board, and professional advisors or mentors, amongst others. The biggest challenge for sibling partners, especially successor partners, is to develop good working relationships, characterised by cooperation and trust, with key non-family employees (Lansberg, 1999). The relationship between family and non-family members lends a unique dimension to a family business; poor relationships could cause conflict and spell disaster for the business (Maas et al., 2005).

Anecdotal and empirical evidence supporting the inclusion of each of these groups of people in the hypothesised relationships will now be discussed. 


\section{PARENTAL INVOLVEMENT}

An overwhelming amount of anecdotal evidence exists, suggesting that parents impact the success of a Sibling Partnership (Aronoff et al., 1997; Swogger, 1991; Ward, 2004). This influence of parents on the ability of siblings to work together, on their relationship, and on the success of the family business, occurs as a result of both the past (Aronoff et al., 1997; Cater \& Justis, 2009; Friedman, 1991; Lansberg, 1999; Ward, 2004) and the present (Cater \& Justis, 2009; De Massis, Chau, Chrisman, 2008; Friedman, 1991; Harvey \& Evans, 1995; Lansberg, 1999; Sharma, 2004) behaviour of parents. According to Swogger (1991), rigid emotional ties to parents can paralyse a successor generation. Similarly, Handler (1992) concludes that the degree of individuation or differentiation that exists in parents has important implications for the successor's quality of experience of the succession process.

If parents are alive they can continue to exercise enormous influence on the sibling team (Aronoff et al., 1997). For example, the continued presence of the senior generation in the family business can act as an annoyance to other family members and employees involved in the business (Aronoff et al., 1997; Davis \& Harveston, 1999; Harvey \& Evans, 1995). Davis and Harveston (1999) report that conflict is higher among second-generation family firms when the founder or spouse remains active in the family business, than when he or she is no longer active. The propensity of owner-managers to step aside is an important influencer of the successors' satisfaction with the succession process (Sharma, 1997; Sharma, Chua \& Chrisman, 2000), and the reluctance of the founder to step down is one of the dominant drivers of failed successions (Ciampa \& Watkins, 1999; De Massis et al., 2008). Against this background the following hypotheses are subjected to further empirical testing:

$H^{3 a}$ : There is a positive relationship between Parental involvement and the perceived Financial performance of the Sibling Partnership.

$H^{3 b}$ : There is a positive relationship between Parental involvement and the level of Family harmony existing in the Sibling Partnership.

$H^{3 c}$ : There is a positive relationship between Parental involvement and the Perceived success of the Sibling Partnership.

\section{INVOLVEMENT OF OTHER FAMILY MEMBERS}

Non-active sibling shareholders are able to exercise considerable influence on the ability of the siblings to work together, and on the success of the Sibling Partnership (Aronoff et al., 1997; Brigham, 2004; Gersick et al., 1997; Lansberg, 1999; Maas et al., 2005; Van der Heyden, Blondel \& Carlock, 2005). According to Lambrecht and Lievens (2008:298), ownership held by numerous family shareholders can lead to increased family complexity and ultimately inhibited growth and reduced performance. Furthermore, Molly et al. (2010) assert that an increase in the number 
of passive family shareholders may lead to intrafamily conflicts. The influence of dissatisfied non-active sibling shareholders manifests itself in a variety of ways, amongst others, through the sabotaging of business operations, interfering with business decisions, and stimulating conflict (Underpowered Sibling or Cousin Syndicates? 2003; Maas et al., 2005). Non-active sibling shareholders whose financial and participation needs are satisfied, are, however, good for both the business and the family (Gersick et al., 1997; Lansberg, 1999). Poza (2010) asserts that successful family firms require the management of relationships with both active and non-active family members.

The behaviour of spouses/in-laws is an especially important factor that influences whether the sibling team will be able to work together successfully and in a manner that is reasonably harmonious (Aronoff et al., 1997; Galbraith, 2003; Gersick et al., 1997; Lansberg, 1999; Schiff Estess, 1999). According to Van Auken and Werbel (2006), a spouse's willingness to contribute to the family business, directly or indirectly, can be seen as a core family variable, influencing financial performance. Regardless of a spouse's degree of direct participation in the business, spousal behaviour permeates family relationships and can affect business performance by influencing the entrepreneur's attitudes, resources, and motivation toward the business (Poza \& Messer, 2001; Van Auken \& Werbel, 2006).

The joining of spouses/in-laws makes family relationships more complicated, conflict normally intensifies (Fishmen, 2009; Zheng, 2002) and in-laws are often seen as being responsible for this (Aronoff et al., 1997; Gersick et al., 1997; Lansberg, 1999). Davis and Harveston (1999) reveal that conflict is higher among second-generation family firms when the spouse remains active in the family business and lower when the spouse is no longer active in the family business. In their study Fahed-Sreih and Djoundourian (2006) find that non-family members in leading positions seem to be more acceptable than spouses/in-laws in these positions. The following hypotheses are subjected to further testing:

$H^{4 a}$ : There is a positive relationship between the involvement of Other family members and the perceived Financial performance of the Sibling Partnership.

$H^{4 b}$ : There is a positive relationship between the involvement of Other family members and the level of Family harmony existing in the Sibling Partnership.

$H^{4 c}$ : There is a positive relationship between the involvement of Other family members and the Perceived success of the Sibling Partnership. 


\section{NON-FAMILY INVOLVEMENT}

Outsiders or non-family members have an important impact on the success and growth of the family business (Claver, Rienda, Quer, 2009; De Massis et al., 2008; Eybers, 2010; Poza, 2010; Sundaramurthy, 2008; Sharma, 2004; Ward, 2004). For example, the use of non-family or outside advisors such as jurists, fiscal experts, business economists, psychologists, and therapists has been advocated among family businesses (Barach \& Gantisky, 1995; Donckels \& Lambrecht, 1999; Passing on the crown, 2004; Ward, 2004). In his research, Sorenson (2000) finds that consulting with outside professionals is highly correlated with both business (financial) and family outcomes. Similarly, Eybers (2010) reports significantly positive relationships between the involvement of non-family members in copreneurships and the financial and growth performance of these businesses. Furthermore, in her study Gladstein (1984) finds that technical consultation with others by team members is positively associated with self-reported measures of team effectiveness. Outsider expertise improves the quality of discussions about strategy, improves decisionmaking, and increases the chances of business survival (Mustakallio, Autio \& Zahra, 2002). Sundaramurthy (2008:89) asserts that outsiders serve as critical "trust catalysts", building bridges between siblings and other subordinates. Sufficient anecdotal and empirical evidence is presented above to hypothesise that:

$H^{5 a}$ : There is a positive relationship between the involvement of Non-family employees and the perceived Financial performance of the Sibling Partnership.

$H^{5 b}$ : There is a positive relationship between the involvement of Non-family employees and the level of Family harmony existing in the Sibling Partnership.

$H^{5 c}$ : There is a positive relationship between the involvement of Non-family employees and the Perceived success of the Sibling Partnership.

\section{METHODOLOGY}

\section{Scale Development}

Each factor under investigation (construct) was operationalised using reliable and valid items sourced from validated measuring instruments used in previous empirical studies, as well as several self-generated items based on secondary sources. Where necessary the items were rephrased to make them more suitable for the present study, and then used to empirically test the relationships hypothesised in Figure 1. 


\section{Sampling and Data Collection}

A convenience snowball sampling technique was employed for this study. Two databases of family businesses were, however, identified and used to initiate the sampling process. In total 1323 potential respondents were identified. This sampling technique and methodology are consistent with those of other family business researchers who have been constrained by the lack of a national database on family firms (Sonfield \& Lussier, 2004; Van Der Merwe \& Ellis, 2007; Venter, 2003).

In the present study the survey technique was employed and a self-administered structured questionnaire was distributed to potential respondents. Section 1 of the questionnaire consisted of 37 statements (items) relating to the involvement of the various family and non-family members (stakeholders) in the sibling team. Using a seven-point Likert-type interval scale, respondents were requested to indicate their extent of agreement with regard to each statement. Demographic information pertaining to both the respondent and the family business was requested in Section 2.

The data collected from 371 usable questionnaires was subjected to various statistical analyses. An exploratory factor analysis was undertaken and Cronbachalpha coefficients calculated to assess the discriminant validity and reliability of the measuring instrument respectively. The relationships proposed in the hypothesised model (Figure 1) were assessed by means Structural Equation Modelling (SEM).

\section{Sample Description}

The vast majority of respondents were male (80.6\%), white (95.4\%) and actively employed (93.3\%) in the Sibling Partnership. An average age of 40 years was reported, with the majority (72.5\%) being younger than 45 years. Most respondents (36.7\%) were an oldest child, with $33.2 \%$ being a middle child, and $30.2 \%$ a youngest child. Although $29 \%$ of sibling teams consisted of both males and females, the majority $(64.2 \%)$ of teams consisted of males only. The average team consisted of 2.48 siblings, with an average age difference of 5.66 years between siblings involved in the business. On average the siblings had been in business together for 11.44 years, with the majority $(56.8 \%)$ having been in business together for less than 10 years.

Of the sibling owned/managed businesses participating in the study, $26.7 \%$ operated in the agricultural industry, $19.4 \%$ in the retail, $15.1 \%$ in the manufacturing and $11.3 \%$ in the finance/business services industries. The majority (73\%) of businesses employed 50 persons or less and 24\% indicated employment of fewer than 10 employees. Of the participating businesses, $24 \%$ indicated having been operating for 
10 years or less, whereas quite a large percentage $(21 \%)$ had been operating for more than 50 years. The oldest business, a business that had been passed down from one family generation to another, was reported as being 265 years old.

\section{Discriminant Validity and Reliability Results}

Before conducting a SEM analysis the number of factors and the items loading onto each factor must be known (Hair, Black, Babin, Anderson \& Tatham, 2006). For this reason an exploratory factor analysis using SPSS 15 for Windows was conducted to identify the unique factors present in the data prior to implementing SEM. In order to conduct the exploratory factor analyses, the data were divided into two models. The first model related to the intervening and dependent variables, whereas the second to the independent variables. In identifying the factors (constructs) to extract for each model, the percentage of variance explained and the individual factor loadings were considered.

Because of the relational nature of the dependent and intervening variables, a Principal Axis Factoring with an Oblique (Oblimin with Kaiser normalisation) Rotation was specified as the extraction and rotation method. Bartlett's Test of Sphericity reported a KMO of $0.94 \quad(p<0.001)$, which confirmed that the data are factoranalysable. The exploratory factor analysis was unable to confirm all the latent variables as originally intended in the hypothesised model (Figure 1). The original latent variable Financial performance split into two variables, which were subsequently named Financial performance and Growth performance. The original dependent variable Perceived success and the intervening variable Family harmony combined to form a new dependent variable. This variable was renamed Satisfaction with work and family relationships. These three factors explain $75.48 \%$ of the variance in the data and are regarded as the dependent variables in this study.

For the independent variables it was not expected that the factors would be correlated, consequently Principal Component Analysis with a Varimax Rotation was specified as the extraction and rotation method. Bartlett's Test of Sphericity reported a KMO of $0.793(p<0.001)$, indicating that the data are factor-analysable. The original factor Parental involvement split into two factors and these were renamed Past parent involvement and No present parent involvement. Of the original eight items expected to measure the construct Parental involvement, three items loaded together onto one factor. These three items were all negatively phrased, and this factor was renamed No present parent involvement. The items intended to measure the involvement of other family members loaded onto one factor as expected. Because of the negative phrasing of these items it was decided to rename this factor No other family member involvement. The factor Non-family employees emerged as expected. The four factors extracted explain $60.04 \%$ of the variance in the data. 
Items that displayed no cross-loadings, that loaded to a significant extent on one factor only, and reported factor loadings of $\geq 0.4$, were considered significant and retained for further analysis (Hair et al., 2006). Factor loadings of $\geq 0.4$ were reported for all factors. Consequently evidence of construct and discriminant validity for the measuring instrument is provided.

Cronbach-alpha coefficients of greater than 0.70 (Nunnally \& Bernstein, 1994) were returned for all constructs. The Cronbach-alpha coefficients consequently suggest that reliable measuring scales were used to measure the constructs under investigation. Table 1 summarises the operational definitions of factors as well as details concerning the validity and reliability of the measuring instrument.

Table 1 Measurement instrument analyses*

\begin{tabular}{|l|c|c|c|}
\hline Operationalisation of factors & Item & Loadings & $\begin{array}{c}\text { Cronbach } \\
\text { Alpha }\end{array}$ \\
\hline $\begin{array}{l}\text { Past parent involvement refers to the parents being } \\
\text { involved in the lives of the siblings and in their relationship } \\
\text { with each other, while they were growing up. }\end{array}$ & 5 & $\begin{array}{c}\text { Max: } 0.878 \\
\text { Min: } 0.584\end{array}$ & 0.861 \\
\hline $\begin{array}{l}\text { Non-family involvement refers to the non-family members } \\
\text { being involved in the family business }\end{array}$ & 6 & $\begin{array}{c}\text { Max: } 0.821 \\
\text { Min: } 0.619\end{array}$ & 0.817 \\
\hline $\begin{array}{l}\text { No other family member involvement refers to non-active } \\
\text { sibling shareholders and spouses of sibling partners not } \\
\text { getting involved, or else interfering in either the business or } \\
\text { the relationship between the sibling partners. }\end{array}$ & 4 & $\begin{array}{c}\text { Max: } 0.840 \\
\text { Min: } 0.785\end{array}$ & 0.864 \\
\hline $\begin{array}{l}\text { No present parent involvement refers to parent(s) not being } \\
\text { dependent on the business and not presently being } \\
\text { involved or interfering in the business or in the present-day } \\
\text { relationship between the siblings. }\end{array}$ & 3 & $\begin{array}{c}\text { Max: } 0.850 \\
\text { Min: } 0.763\end{array}$ & 0.744 \\
\hline $\begin{array}{l}\text { Financial performance refers to the business being } \\
\text { financially profitable and secure. }\end{array}$ & 3 & $\begin{array}{l}\text { Max: } 0.910 \\
\text { Min: } 0.650\end{array}$ & 0.877 \\
\hline $\begin{array}{l}\text { Growth performance refers to the business showing growth } \\
\text { in the number of employees, profits and revenues. }\end{array}$ & 3 & $\begin{array}{l}\text { Max: } 0.933 \\
\text { Min: } 0.538\end{array}$ & 0.781 \\
\hline $\begin{array}{l}\text { Satisfaction with work and family relationships refers to } \\
\text { harmonious relationships existing among family members } \\
\text { (i.e. relationships characterised by closeness, caring and } \\
\text { support, appreciation of each other, and concern for each } \\
\text { other's welfare) as well the siblings finding their working } \\
\text { relationship in the Sibling Partnership as satisfying. }\end{array}$ & 10 & $\begin{array}{l}\text { Max: } 0.904 \\
\text { Min: } 0.766\end{array}$ & 0.961 \\
\hline
\end{tabular}

* See Appendix A for a detailed description of multiple item scales measuring factors. 


\section{Modified Hypotheses}

As a result of the exploratory factor analyses, it was deemed necessary to reformulate the original hypotheses or the hypothesised model (Figure 1), which are summarised below:

$H^{1}$ : There is a positive relationship between the perceived Financial performance of the Sibling Partnership and the Satisfaction with work and family relationships.

$H^{2}$ : $\quad$ There is a positive relationship between the level of Growth performance of the Sibling Partnership and the Satisfaction with work and family relationships.

$H^{3}$ : $\quad$ There is a positive relationship between the level of Growth performance of the Sibling Partnership and the perceived Financial performance of the Sibling Partnership.

$H^{4 a-4 c}$ : There is a positive relationship between Past parent involvement and the perceived Financial performance $\left(H^{\text {ta }}\right)$, the level of Growth performance $\left(H^{4 b}\right)$, and Satisfaction with work and family relationships $\left(H^{4 c}\right)$.

$H^{5 a-5 c}$ : There is a positive relationship between No present parent involvement and the perceived Financial performance $\left(H^{5 a}\right)$, the level of Growth performance $\left(H^{5 b}\right)$, and the Satisfaction with work and family relationships $\left(H^{5 c}\right)$.

$H^{6 a-6 c}$ : There is a positive relationship between No other family member involvement and the perceived Financial performance $\left(H^{6 a}\right)$, the level of Growth performance $\left(H^{6 b}\right)$, and the Satisfaction with work and family relationships $\left(H^{6 c}\right)$.

$H^{7 a-7 c}$ : There is a positive relationship between the Non-family member involvement and the perceived Financial performance $\left(H^{7 a}\right)$, the level of Growth performance $\left(H^{7 b}\right)$, and the Satisfaction with work and family relationships $\left(H^{7 c}\right)$.

As mentioned above, the factor analysis resulted in the original latent variable Financial performance splitting into two variables, namely Financial performance and Growth performance. Ample empirical evidence exists to suggest that the growth performance of a business has a positive impact on its financial performance (Brigham \& Daves, 2007; Ittner \& Larcker, 1998). An analysis of 88 different studies has shown that growth is consistently related to higher levels of financial performance (Capon, Farley \& Hoenig, 1990). Consequently an additional hypothesis was formulated (see $\mathrm{H}^{3}$ above) to test this relationship. 


\section{Structural Equation Modeling Results}

The hypothesised relationships were portrayed in path diagrams, and the structural and the measurement models were specified. A covariance matrix was used as the input matrix. As the data in the present study showed evidence of non-normality (the skewness and kurtosis of the data reported p-values of 0.000 ), Robust Maximum Likelihood, which compensates for non-normality of the data, was used for obtaining estimates of the free parameters (Hoogland \& Boomsma, 1998; Satorra \& Bentler, 1994). Indicator loadings for both the measurement and the structural models were evaluated for significance by ensuring that the $p$-value associated with each loading exceeded either the critical value for the $5 \%$ (critical value 1.96) significance level, the $1 \%$ (critical value 2.58) significance level (Reisinger \& Turner, 1999) or even the $0.1 \%$ significance level (critical value of 3.30 ).

To establish the extent to which the proposed model represents an acceptable approximation of the data, various fit indices were considered. A ratio of $\chi^{2}$ to degrees of freedom of 2.42 is reported, which is higher than the acceptable 2. Values lower than 2 are indicators of a good fit (Hair, Anderson, Tatham \& Black, 1998). The RMSEA (0.0619) falls within the acceptable fit range of between 0.05 0.08 (Grimm \& Yarnold, 2000; Hair et al., 1998), while the upper limit of the $90 \%$ confidence interval for RMSEA (0.0674) is less than 0.08 (Boshoff, 2005; Roberts, Stephen \& llardi, 2003). Apart from the ratio $\chi^{2}$ to degrees of freedom, the indices provide evidence that although the data does not fit the model perfectly, it can be described as having a reasonable fit.

\section{Significant Relationships Identified by SEM}

In Figure 2 below, only the significant relationships identified by SEM are depicted. The empirical findings show that the Growth performance of the business is positively related (path coefficient $=0.23, p<0.001$ ) to Satisfaction with work and family relationships (hypothesis $H^{2}$ ). Similarly, the Growth performance of the business is positively related (path coefficient $=0.71, p<0.001$ ) to its perceived Financial performance (hypothesis $H^{3}$ ). Support was thus found for Hypotheses $H^{2}$ and $H^{3}$. No significant relationship is reported between perceived Financial performance (hypothesis $H^{1}$ ) and the Satisfaction with work and family relationships. This finding suggests that the financial performance of the business has no impact on whether the siblings experience their work and family relationships as satisfying. Hypothesis $H^{1}$ could thus not be supported. 


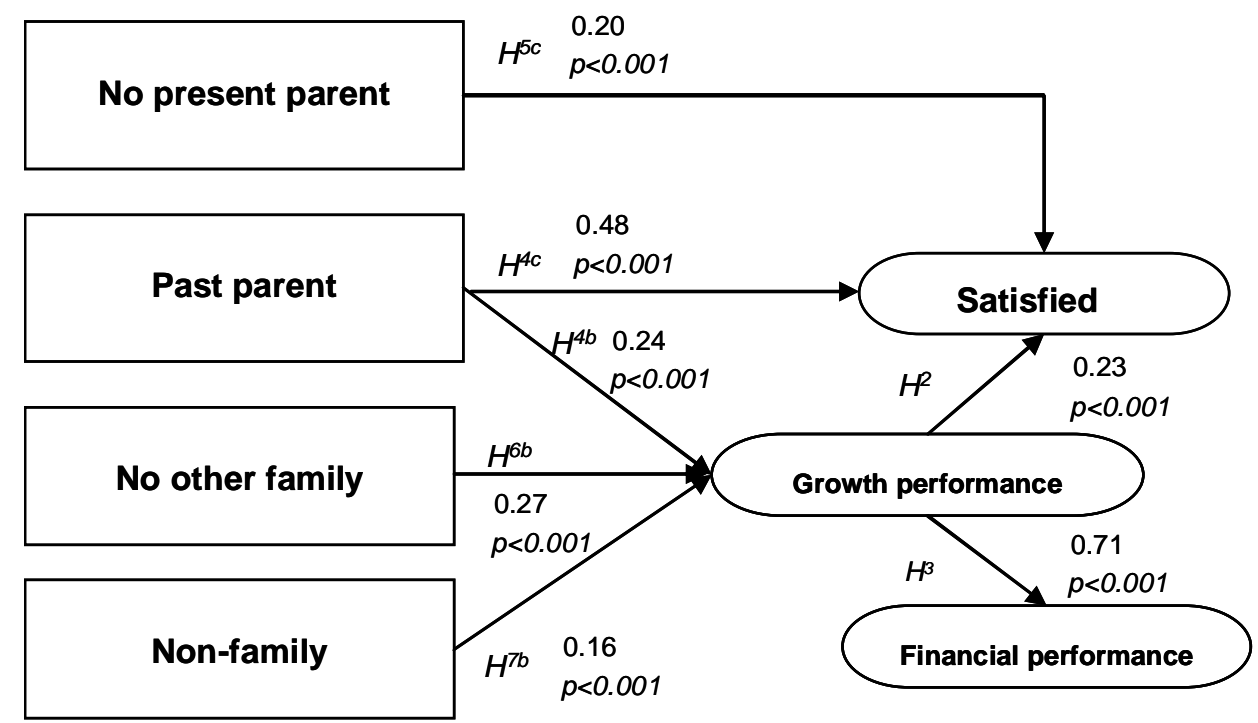

* Satisfied = Satisfaction with work and family relationships

Figure 2 Model of family and non-family members influencing the level of Satisfaction with work and family relationships in Sibling Partnerships

Significant positive relationships were found between Past parent involvement (path coefficient $=0.24, \mathrm{p}<0.001$ ) and Growth performance (hypothesis $H^{4 b}$ ), as well as between Past parent involvement (path coefficient $=0.48, p<0.001$ ) and Satisfaction with work and family relationships (hypothesis $H^{49}$ ). Support was thus found for Hypotheses $H^{4 b}$ and $H^{4 c}$. The respondents in this study are thus of the opinion that the more their parents were involved in their lives and in their relationships while they were growing up, the more likely their business is to experience Growth performance, and the more likely they are to be being satisfied with their current work and family relationships. A relationship between Past parent involvement and perceived Financial performance (hypothesis $H^{4 a}$ ) could not be empirically confirmed. Whether the parents of siblings were involved in their lives or their relationships during childhood or not, had no influence on the financial performance of the Sibling Partnership. Hypothesis $H^{4 a}$ could thus not be supported.

The empirical findings in this study concur with a vast amount of anecdotal and empirical evidence that suggests that the behaviour of parents during the childhood years of siblings has a significant influence on the ability of those siblings to work together as adults (Aronoff et al., 1997; Lansberg, 1999; Swogger, 1991; Ward, 2004).

The empirical results of this study found no significant relationship between No present parent involvement and perceived Financial performance (hypothesis $H^{5 a}$ ), nor between No present parent involvement and Growth performance (hypothesis 
$\left.H^{5 b}\right)$. This result implies that whether parents are involved or get involved in the business and in the present-day relationship between the siblings or not, has no influence on the perceived Financial performance or the Growth performance of the business. Support was thus not found for hypotheses $H^{5 a}$ and $H^{5 b}$. A significant positive relationship was, however, identified between No present parent involvement (path coefficient $=0.20, p<0.001$ ) and Satisfaction with work and family relationships (hypothesis $\mathrm{H}^{5 \mathrm{C}}$. In other words, the less the parents of siblings are currently involved and/or interfere in the business and in the present-day relationship between the siblings, the more likely the siblings are to experience their work and family relationships as satisfying. Support was thus found for Hypothesis $H^{5 c}$.

An overwhelming amount of anecdotal and empirical evidence suggests that the present involvement and/or interference of parents in the business and in the present-day relationship between the siblings, has an impact on the ability of siblings to work together as adults (Lansberg, 1999; Sharma, 2004:10; Ward, 2004; Davis \& Harveston, 1999).

The empirical results of this study indicate that there is a positive relationship (path coefficient $=0.27, p<0.001$ ) between the constructs No other family member involvement and Growth performance. The respondents in this study are thus of the opinion that the less non-active sibling shareholders and spouses of sibling partners are involved and/or interfere in the business, the better the growth performance of the business will be. Support is thus found for hypothesis $H^{6 b}$.

No significant relationships were, however, found between No other family member involvement and Satisfaction with work and family relationships (hypothesis $H^{60}$ ), or between No other family member involvement and perceived Financial performance (hypothesis $H^{6 a}$ ). This finding implies that whether spouses or non-active sibling shareholders get involved and/or interfere in the business and in the relationship between the siblings or not, has no influence on the financial performance of the business, or on the siblings being satisfied with their work and family relationships. Support was thus not found for hypotheses $H^{6 a}$ and $H^{6 c}$. The findings of this study contradict a vast amount of anecdotal evidence supporting that both non-active sibling shareholders (Brigham, 2004; Lansberg, 1999; Maas et al., 2005:104; Van der Heyden et al., 2005) and spouses (Galbraith, 2003; Gersick et al., 1997; Lansberg, 1999; Schiff Estess, 1999) exercise considerable influence on the ability of the siblings to work together, and on the success of the Sibling Partnership.

From Figure 2 it can be seen that the variable Non-family involvement is positively related (path coefficient $=0.16, p<0.001$ ) to Growth performance (hypothesis $H^{7 b}$ ), indicating that the participating siblings believed that the more non-family members are involved in the business, the better the growth performance of their business will 
be. Support is thus found for hypotheses $H^{7 b}$. The empirical results in this study are consistent with the findings of various other authors (Mustakallio et al., 2002; Sharma, 2004; Ward, 2004), who suggest a positive relationship between the involvement of non-family members in the family business and business performance. In contrast to the aforementioned empirical and anecdotal evidence, no significant relationship was found between Non-family involvement and perceived Financial performance. Hypothesis $H^{7 a}$ could thus not be supported

Although anecdotal evidence exists suggesting that non-family members can play a key role in maintaining positive relationships (Aronoff et al., 1997; Lansberg, 1999; Maas et al., 2005) or in creating conflicts (Harvey \& Evans, 1995; Neubauer, 2003) among family members, no significant relationship was identified between Nonfamily involvement and Satisfaction with work and family relationships (hypothesis $\mathrm{H}^{79}$ in the present study. The respondents in this study were of the opinion that nonfamily members being involved in the business or not, had no influence on their being satisfied with their work and family relationships. Hypothesis $\mathrm{H}^{7 \mathrm{c}}$ could thus not be supported. This finding is also in contrast to the research of Sorenson (2000), who reports that consulting with outside professionals is highly correlated with family outcomes.

\section{CONCLUSIONS AND RECOMMENDATIONS}

The results of this study indicate that the Growth performance of the Sibling Partnership exerts a significant positive influence on the Financial performance of the business and on the Satisfaction with work and family relationships. Siblings are more likely to be satisfied with their working and family relationships, and the business is more likely to perform financially, when evidence of growth in sales, employees and profits exists. No significant relationships were identified between the other independent variables and Financial performance. However, significant relationships were identified between Past parent involvement, No other family member involvement and Non-family involvement and Growth performance, suggesting the that these factors indirectly affect perceived Financial performance through their influence on Growth performance. Similarly, no significant relationship was identified between the independent variables No other family member involvement and Non-family involvement, and the dependent variable Satisfaction with work and family relationships. Significant relationships were, however, found between the aforementioned independent variables and Growth performance, suggesting that No other family member involvement and Non-family involvement variables indirectly affect Satisfaction with work and family relationships through their influence on Growth performance. 
The involvement of non-family members in a Sibling Partnership has a significant positive influence on the growth performance of the business. Non-family members include, amongst others, non-family employees, the directors of the board, and professional advisors or mentors. Non-family members make a vital contribution through expanding the knowledge base of the family business by bringing additional qualifications and skills, assisting with resolving conflict, showing objectivity, and promoting accountability and professionalism. It is also important that loyalty and respect for the family business leaders be developed among non-family employees and other outsiders. In addition, care should be taken that non-family members do not play the siblings off against each other. Sibling partners should be in agreement and have a clear policy on non-family involvement.

The findings of this study suggest that parents who set a good example, assist and encourage their children, and are involved in the lives of their children while they are growing up, contribute to better relationships between their children as adults. Children frequently develop patterns in reaction to what they see their parents do, and several aspects relating to the behaviour of parents and their parenting style, affect the ability of the siblings to work together as adults. Parents can, for example, start early in encouraging the development of skills such as sharing and collaboration, which will be necessary for a sibling relationship to survive when the children begin working together as adults. Skills such as the ability to communicate, to think outside of own interests, to make decisions, to seek consensus, and the capacity to want fairness and justice for all, are the skills that are best learned while growing up in one's own family. Parents can set good examples for their children by not being autocratic, manipulative or neglectful of their children. In addition, parents should treat all their children equally, and not be guilty of stereotyping or judging any one child. The results of this study highlight the important role that good parenting and a happy and stable childhood have on the future success of the family business. Family business owners would do well to keep this in mind when nurturing the family business's future leaders.

In contrast to the influence of past parent involvement in the lives of siblings, the findings of this study suggest that the less that parents are involved, or get involved in the business and in the present-day relationship between the siblings, the better the present-day relationship between the siblings is likely to be. If parents are alive, whether they are involved in the family business or not, they can continue to exercise an enormous influence on the sibling team. To ensure that this influence is positive, parents should keep their involvement and interference in the family business to a minimum, and not act as arbitrator between siblings or interfere in conflict between them. Parents should also display a willingness to let go, and to undertake proper exit planning (succession, estate and strategic planning). By transferring their 
knowledge, information and networks, as well as trusting the ability of the successors, parents show support and endorse the new leaders.

The less other family members (non-active siblings and spouses) are involved or get involved in the business and in the present-day relationship between the siblings, the better the growth performance of the business is likely to be. It is difficult to be an inlaw in a business-owning family, but the family business needs the spouses to be supportive of both the family and the business. An unhappy and annoyed spouse can threaten the success of a family business, whereas a happy spouse can support it and add to its strength. To successfully manage spousal relationships in a Sibling Partnership, consensus on spousal involvement should firstly exist. In addition, spouses should be welcomed and informed concerning business matters. Spouses themselves should be objective, and as far as possible stay out of sibling and family grievances. In addition, spouses should not interfere in the day-to-day operations of the family business. As in the case of spouses, the existence of non-active siblings presents additional challenges for a Sibling Partnership. If possible, it is best to limit the involvement and number of non-active siblings, specifically those who are shareholders. Should non-active shareholders exist, their roles and responsibilities should be clarified in a participation agreement or family constitution, and they should be informed regarding business activities. In addition, care should be taken not to allow non-active siblings to interfere in business operations or to play off those siblings working in the business against each other.

\section{IMPLICATIONS FOR FUTURE RESEARCH}

Three constructs were proposed to measure success in the initial hypothesised model, namely Family harmony, Financial performance and Perceived success. The exploratory factor analysis, however, revealed that the original six items measuring Financial performance loaded onto two factors, which were renamed Financial performance and Growth performance. To deem growth and profitability as independent opposing measures of business performance is not unusual in the literature (Cubbin \& Leech, 1986; Geringer, Frayne \& Olsen, 1998; Small Firm Survey, 2007-2008). Six items were originally formulated to measure Family harmony and five to measure Perceived success. These items unexpectedly loaded together onto one construct. As a result three new factors emerged to measure success in this study, namely Financial performance, Growth performance and Satisfaction with work and family relationships. Astrachan (2006) proposes that no single measure of performance is likely to capture the complexities of the family business; the results of this study support this proposition. The findings of this study present the family business researcher with three possible constructs for measuring different aspects of family business success. 
In this study the factor measuring the involvement of parents in the lives of siblings, namely Parental involvement, has split into two factors, each reflecting the involvement of parents in the lives of siblings at different stages in their lives. These factors relate to the involvement of parents in the lives of the siblings as children, namely Past parent involvement and the present-day involvement of parents in the lives of siblings, No present parent involvement. The three items that loaded onto the aforementioned factor were all negatively phrased, hence the labelling of this factor. The results of this study show that the involvement of parents in the lives of the siblings as children versus parents' present-day involvement in the lives of siblings have contradictory influences. The more that parents were involved in the lives of the siblings as children the better their adult relationship is likely to be, but the more the parents are involved in the present-day relationship between the siblings, the worse their adult relationships is likely to be. Cleary the present and past influence of parents on the success of a family business are different constructs, and researchers should take cognisance of this when measuring or making conclusions concerning the influence of parents on family succeeding generations.

\section{LIMITATIONS AND FUTURE RESEARCH}

In all empirical studies their limitations must be identified, and considered when making interpretations and conclusions. The use of non-probability snowball convenience sampling is a limitation that introduces a source of potential bias into this study. As such, the findings reported can not be generalised to the general family business population. Another limitation of this study is that the proposed hypothetical model focuses exclusively on a selected number of stakeholders impacting business success. Future studies could investigate various other relational and task-based factors and incorporate them into a more comprehensive model that describes the factors influencing the successful functioning of Sibling Partnerships. In addition, future studies could focus on other family business teams.

Despite the limitations identified, this study has added to the empirical body of family business research, and provides an important first step in gaining insights into important stakeholder groups influencing the effective functioning of family business teams. 


\section{REFERENCES}

Adendorff, C.M. 2004. The development of a cultural family business model of good governance for Greek family businesses in South Africa. Unpublished doctoral thesis, Rhodes University, Grahamstown.

Aronoff, C.E., Astrachan, J.H., Mendosa, D.S. \& Ward, J.L. 1997. Making sibling teams work: The next generation. Family business leadership series. Marietta, GA: Family Enterprise Publishers.

Astrachan, J.H. 2006. Editor's notes. Family Business Review, 19(1):v-vi.

Barach, J.A. \& Gantisky, J.B. 1995. Successful succession in family business. Family Business Review, 8(2):131-155.

Boshoff, C. 2005. A re-assessment and refinement of RECOVSAT. Managing Service Quality, 15(5):410-425.

Brigham, E.F. \& Daves, P.R. 2007. Intermediate Financial Management. $9^{\text {th }}$ ed. Mason, OH: Thomson South-Western.

Brigham, W. 2004. Siblings, don't give up the fight! The Business Review, March 12. [Online] Available from: http://www.bizjournals.com/albany/stories/2004/03/15/focus4.html [Accessed: 2005-02-08].

Campion, M.A., Medsker, G.J. \& Higgs, A.C. 1993. Relations between work group characteristics and effectiveness: Implications for designing effective work groups. Personnel Psychology, 46:823-850.

Campion, M.A., Papper, E.A. \& Medsker, G.J. 1996. Relations between work team characteristics and effectiveness: A replication and extension. Personnel Psychology, 49:429-432.

Capon, N., Farley, J.U. \& Hoenig, S. 1990. Determinants of financial performance: A meta-analysis. Management Science, 36(10):1143-1159.

Casillas, J.C., Moreno, A.M. \& Barbero, J.L. 2010. A configurational approach of the relationship between entrepreneurial orientation and growth of family firms. Family Business Review, 23(1):27-44.

Cater III, J.J. \& Justis, R.T. 2009. The development of successors from followers to leaders in small family firms. Family Business Review, 22(2):109-124.

Ciampa, D. \& Watkins, M. 1999. The successor's dilemma. Harvard Business Review, 77(6):161-168.

Claver, E., Rienda, L. \& Quer, D. 2009. Family firms' international commitment: The influence of family-related factors. Family Business Review, 22(2):125-135.

Cubbin, J. \& Leech, D. 1986. Growth versus profit-maximization: A simultaneousequations approach to testing the Marris Model. Managerial and Decision Economics, 7:123-131.

Davis, P.S. \& Harveston, P.D. 1999. In the founder's shadow: Conflict in the family firm. Family Business Review, 12(4):311-323. 
De Massis, A. Chau, J.H. Chrisman, J.J. 2008. Factors preventing intra-family succession. Family Business Review, 21(2):183-199.

Distelberg, B. \& Sorenson, R.L. 2009. Updating systems concepts in family businesses: A focus on values, resource flow, and adaptability. Family Business Review, 22(1):65-81.

Donckels, R. \& Lambrecht, J. 1999. The re-emergence of family-based enterprises in East Central Europe: What can be learned from family business research in the Western World? Family Business Review, 12(2):171-188.

Doolen, T.L., Hacker, M.E. \& Van Aken, E. 2006. Managing organizational context for engineering team effectiveness. Team Performance Management, $12(5 / 6): 138-154$.

Dyer, W.G. 1986. Cultural change in family firms: Anticipating and managing business and family transitions. In Lee, J. 2006. Impact of family relationships on attitudes of the second generation in family business. Family Business Review, 19(3):175-191.

Eybers, C. 2010. Co-preneurships in South African small and medium-sized family businesses. Unpublished masters dissertation. Port Elizabeth: The Nelson Mandela Metropolitan University.

Fahed-Sreih, J. \& Djoundourian, S. 2006. Determinants of longevity and success in Lebanese family businesses: An exploratory study. Family Business Review, $19(3): 225-234$.

Farrington 2009. Sibling Partnerships in South African small and medium-sized family businesses. Unpublished doctoral thesis, The Nelson Mandela Metropolitan University, Port Elizabeth.

Fishman, A.E. 2009. 9 Elements of family business success. New York, NY: McGraw-Hill.

Flören, R.H. 2002. Crown princes in the clay. Assen, The Netherlands: Royal Van Gorcum.

Friedman, S. D. 1991. Sibling relationships and intergenerational succession in family firms. Family Business Review, 4(1):3-20.

Galbraith, C.S. 2003. Divorce and the financial performance of small family businesses: An exploratory study. In Sund, L. \& Smyrnios, K.X. 2005. Striving for happiness and its impact on family stability: An exploration of Arisotelian conception of happiness. Family Business Review, 18(2):155-171.

Geringer, J.M., Frayne, C.A. \& Olsen, D. 1998. Rewarding growth or profit? Top management team compensation and governance in Japanese MNEs. Journal of International Management, 4:289-309.

Gersick, K.E., Davis, J.A., McCollom Hampton, M.M. \& Lansberg, I. 1997. Generation to generation - Life cycles of the family business. Boston, MA: Harvard Business School Press.

Gladstein, D.L. 1984. Groups in context: A model of task group effectiveness. Administrative Science Quarterly, 29:499-517. 
Goldberg, S.D. 1996. Research note: Effective successors in family-owned businesses: significant elements. Family Business Review, 9(2):185-197.

Grimm, L.G. \& Yarnold, P.R. 2000. Reading and understanding more multivariate statistics. In Adendorff, C.M. 2004. The development of a cultural family business model of good governance for Greek family businesses in South Africa. Unpublished doctoral thesis, Rhodes University, Grahamstown.

Hair, J.F., Anderson, R.E., Tatham, R.L. \& Black, W.C. 1998. Multivariate data analysis. $5^{\text {th }}$ ed. Englewood Cliffs, NJ: Prentice Hall.

Hair, J.F., Black, W.C., Babin, J.B., Anderson, R.E. \& Tatham, R.L. 2006. Multivariate data analysis. $6^{\text {th }}$ ed. Upper Saddle River, NJ: Pearson/Prentice Hall.

Hall, A. \& Nordqvist, M. 2008. Professional management in family businesses: Toward an extended understanding. Family Business Review, 21(1):51-69.

Handler, W.C. 1991. Key interpersonal relationships of next-generation family members in family firms. Journal of Small Business Management, 29(3):21-32.

Handler, W.C. 1992. The succession experience of the next generation. Family Business Review, 5(3):283-307.

Harvey, M. \& Evans, R.E. 1995. Life after succession in the family business: Is it really the end of problems? Family Business Review, 8(1):3-16.

Hoogland, J.J. \& Boomsma, A. 1998. Robustness studies in covariance structure modelling: An overview and a meta-analysis. Sociological Methods and Research, 26:329-367.

Howard, L.W., Foster, S.T. \& Shannon, P. 2005. Leadership, perceived team climate and process improvement in municipal government. International Journal of Quality and Reliability Management, 22(8):769-795.

Ittner, C.D. \& Larcker, D.F. 1998. Are nonfinancial measures leading indicators of financial performance? An analysis of customer satisfaction. Journal of Accounting Research, 36:1-35.

Ivancevich, J., Konopaske, I. \& Matteson., M. 2005. Organisational behavior and management. $7^{\text {th }}$ ed. New York, NY: McGraw-Hill.

Jimenez, R.M. 2009. Research on women in family firms: Current status and future directions. Family Business Review, 22(1):53-64.

Kepner, E. 1991. The family and the firm: A coevolutionary perspective. Family Business Review, 4(4):445-461.

Kets de Vries, M.F.R. 1993. The dynamics of family controlled firms: The good news and the bad news. Organisational Dynamics, 21(Winter):59 -71.

Kreitner, R. \& Kinicki, A. 1995. Organisational behavior. $3^{\text {rd }}$ ed. Chicago, IL: Irwin.

Lambrecht, J. \& Lievens, J. 2008. Pruning the family tree: An unexplored path to family business continuity and family harmony. Family Business Review, 21(4):295-313.

Lansberg, I. 1999. Succeeding generations: Realising the dreams of families in business. Boston, MA: Harvard Business School Press. 
Lee, J. 2006. Family firm performance: Further evidence. Family Business Review, 19(2):103-113.

Lumpkin, G.G., Martin, W. \& Vaughn, M. 2008. Family orientation: Individual-level influences on family firm outcomes. Family Business Review, 21(2):127-138.

Maas, G., Van der Merwe, S. \& Venter, E. 2005. Family business in South Africa: A practical governance guide. Stellenbosch: Content Solutions.

Malone, S.C. 1989. Selected correlates of business continuity planning in the family business. Family Business Review, 2(4):341-353.

Molly, V., Laveren, E. \& Deloof,M. 2010. Family business succession and its impact on financial structure and performance. Family Business Review, 23(2):131-147.

Mount, J. 1996. The blood knot. Inc. Magazine. [Online] Available from: http://www.inc.com/magazine/19960201/1540.html [Accessed: 2006-02-21].

Mustakallio, M., Autio, E. \& Zahra, A. 2002. Relational and contractual governance in family firms: Effects on strategic decision-making. Family Business Review, 15(3):205-222.

Nelton, S. 1996. Team playing is on the rise. Nation's Business, 84(6).

Neubauer, H. 2003. The dynamics of succession in family businesses in Western European countries. Family Business Review, 16(4):269-281.

Northouse, P.G. 2004. Leadership: Theory and practice. $3^{\text {rd }}$ ed. United States of America: Sage.

Nunnally, J.C. \& Bernstein, I.H. 1994. Psychometric theory. $3^{\text {rd }}$ ed. New York, NY: McGraw-Hill.

Passing on the crown. 2004. The Economist, November 4. [Online] Available from: http://www.economist.com/business/displayStory.cfm?story_id=3352686 [Accessed: 2005-06-23].

Poza, E.J. \& Messer, T. 2001. Spousal leadership and continuity in the family firm. Family Business Review, 14(1):25-36.

Poza, E.J. 2010. Family business. $3^{\text {rd }}$ ed. Mason, OH: South-Western Cengage Learning.

Poza, E.J., Alfred, T. \& Maheshwari, A. 1997. Stakeholder perceptions of culture and management practices in family and family firms: a preliminary report. Family Business Review, 10(2):135-155.

Reisinger, Y. \& Turner, L. 1999. Structural equation modelling with Lisrel: Application in tourism. Tourism Management, 20:71-88.

Roberts, M.C., Stephen, S. \& Ilardi, S.S. 2003. Handbook of research methods in clinical psychology. Oxford, England: Blackwell Publishing.

Rodriguez, S.N., Hildreth, G.J. \& Mancuso, J. 1999. The dynamics of families in business: How therapists can help in ways consultants don't. Contemporary Family Therapy, 21(4):453-468.

Royer, S., Simons, R., Boyd, B. \& Rafferty, A. 2008. Promoting family: A contingency model of family business succession. Family Business Review, 21(1):15-30. 
Rutherford, M.W., Muse, L.A. \& Oswald, S.L. 2006. A new perspective on the developmental model for family business. Family Business Review, 19(4):317333.

Santiago, A.L. 2000. Succession experiences in Philippine family businesses. Family Business Review, 13(1):15-40.

Satorra, A. \& Bentler, P.M. 1994. Corrections to test statistics and standard errors in covariance structure analysis. In Von Eye, A. \& Clogg, C.C. Eds. Latent variable analysis: Applications to developmental research. Newbury Park: Sage.

Schiff Estess, P. 1999. In-laws and order. Entrepreneur Magazine, April. [Online] Available from: http://www.entrepreneur.com/article/0,4621,230146,00.html [Accessed: 2007-01-25].

Sharma, P. 1997. Determinants of the satisfaction of the primary stakeholders with the succession process in family firms. Unpublished doctoral thesis, University of Calgary, Calgary.

Sharma, P. 2004. An overview of the field of family business studies: Current status and directions for the future. Family Business Review, 17(1):1-36.

Sharma, P., Chua, J.H. \& Chrisman, J.J. 2000. Perceptions about the extent of succession planning in Canadian family firms. Canadian Journal of Administrative Sciences, 17(3):233-244.

Small Firm Survey. 2007-2008. Zweig White information services. [Online] Available

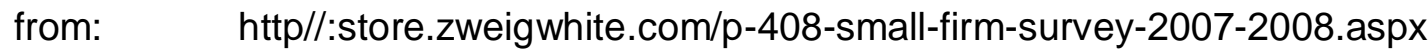
[Accessed: 2008-05-28].

Sonfield, M.C. \& Lussier, R.N. 2004. First-second and third-generation family firms: A comparison. Family Business Review, 17(3):189-202.

Sorenson, L.R. 2000. The contribution of leadership style and practices to family and business success. Family Business Review, 13(3):183-200.

Stakeholder theory. 2006. Wikipedia free encyclopaedia. [Online] Available from: http://en.wikipedia.org/wiki/Stakeholder theory [Accessed: 2006-10-17].

Stewart-Gross, B.L. \& Gross, M.J. 2007. Sleeping with your business partner. Sterling, Virginia: Capital Books, Inc.

Strategic stakeholder management. 1999. Academy of Management Journal, 42(5). [Online] Available from:

http://www.l2manage.com/methods_strategic_stakeholder__ management.html [Accessed: 2007-02-09].

Sundaramurthy, C. 2008. Sustaining trust within family businesses. Family Business Review, 21(1):89-102.

Swogger, G. 1991. Assessing the successor generation in family businesses. Family Business Review, 4(4):397-411.

Underpowered sibling or cousin syndicates? 2003. Centre for Family Business Dynamics. [Online] Available from: http://www.fambus.com/Home/sibling_syndicates2.htm [Accessed: 2006-02-08]. 
Van Auken, H. \& Werbel, J. 2006. Family dynamic and family business financial performance: Spousal commitment. Family Business Review, 19(1):49-63.

Van der Heyden, L., Blondel, C. \& Carlock, R.S. 2005. Fair process: Striving for justice in family business. Family Business Review, 18(1):1-21.

Van der Merwe, S.P. \& Ellis, S. 2007. An exploratory study of some of the determinants of harmonious family relationships in small and medium-sized family businesses. Management Dynamics, 16(4):24-35.

Venter, E. 2003. The succession process in small and medium-sized family businesses in South Africa. Unpublished doctoral thesis, University of Port Elizabeth, Port Elizabeth.

Venter, E., Farrington, S. M. \& Boshoff, H.C. 2009. Selected relational-based factors that impact on the successful functioning of copreneurial businesses: A proposed conceptual model. Management Dynamics, 18(22):2-20.

Ward, J.L. 1987. Keeping the family business healthy: How to plan for continuing growth, profitability and family leadership. San Francisco, CA: Jossey-Bass.

Ward, J.L. 1997. Growing the family business: Special challenges and best practices. Family Business Review, 10(4):323-337.

Ward, J.L. 2004. Perpetuating the family business. 50 lessons learned from longlasting successful families in business. New York, NY: Palgrave Macmillan.

Zbar, J. 2004. Chemistry and consideration: Running a family business is often more about managing relationships than numbers. Florida Trend, 3(47):93.

Zellweger, M.T. \& Nason, R.S. 2008. A stakeholder perspective on family firm performance. Family Business Review, 21(3):203-216.

Zheng, V. 2002. Inheritance, Chinese family business and economic development in Hong Kong. Journal of Enterprising Culture, 10(4):287-312. 


\section{APPENDIX A}

\section{SATISFACTION WITH WORK AND FAMILY RELATIONSHIPS}

\begin{tabular}{|c|l|}
\hline HARM6 & Relationships among members in our family can be described as positive. \\
\hline PSUCC1 & I am satisfied with the way that my sibling(s) and I work together. \\
\hline HARM2 & The members of our family are in harmony with each other. \\
\hline HARM3 & The members of our family are supportive of each other. \\
\hline HARM4 & Our family members appreciate each other. \\
\hline PSUCC3 & I enjoy working with my siblings in our family business. \\
\hline PSUCC5 & $\begin{array}{l}\text { I experience my involvement in this business together with my sibling(s) as } \\
\text { rewarding. }\end{array}$ \\
\hline PSUCC4 & I experience my involvement in this business together with my sibling(s) as fulfilling \\
\hline PSUCC2 & $\begin{array}{l}\text { I am satisfied with the functioning of the working arrangement between my } \\
\text { sibling(s) and I. }\end{array}$ \\
\hline HARM5 & Our family members care about each other's welfare. \\
\hline FINANCIAL PERFORMANCE \\
\hline FIN5 & I regard our family business as being financially successful. \\
\hline FIN3 & Our family business is profitable. \\
\hline FIN6 & The financial well-being of our family business is secure. \\
\hline GROWTH PERFORMANCE \\
\hline FIN1 & Our family business has experienced growth in turnover over the past two years. \\
\hline FIN4 & Our family business has experienced growth in profits over the past two years. \\
\hline two years.
\end{tabular}




\section{APPENDIX A - continued}

\begin{tabular}{|c|c|}
\hline \multicolumn{2}{|c|}{ PAST PARENT INVOLVEMENT } \\
\hline PARENT3 & $\begin{array}{l}\text { During our childhood our parents taught my sibling(s) and I how to deal with } \\
\text { conflict. }\end{array}$ \\
\hline PARENT4 & $\begin{array}{l}\text { During our childhood our parents taught my sibling(s) and I how to cooperate } \\
\text { with others. }\end{array}$ \\
\hline PARENT2 & $\begin{array}{l}\text { During our childhood our parents encouraged my sibling(s) and I to share our } \\
\text { feelings. }\end{array}$ \\
\hline PARENT5 & $\begin{array}{l}\text { During our childhood our parents taught my sibling(s) and I to treat each other } \\
\text { fairly. }\end{array}$ \\
\hline PARENT1 & $\begin{array}{l}\text { Our parents support (supported if deceased) and encourage (encouraged if } \\
\text { deceased) my siblings and I in managing our family business. }\end{array}$ \\
\hline \multicolumn{2}{|c|}{ NON-FAMILY INVOLVEMENT } \\
\hline NONF3 & $\begin{array}{l}\text { In our family business we involve non-family members in assisting us to } \\
\text { effectively managing our business. }\end{array}$ \\
\hline NONF4 & $\begin{array}{l}\text { In our family business we involve non-family members when we have to make } \\
\text { important strategic decisions about our business. }\end{array}$ \\
\hline NONF1 & $\begin{array}{l}\text { In our family business we sometimes approach non-family members to advise us } \\
\text { on business matters. }\end{array}$ \\
\hline NONF6 & In our family business non-family employees form part of the management team. \\
\hline NONF2 & $\begin{array}{l}\text { If necessary we draw on the expertise of non-family members to assist us with } \\
\text { business matters. }\end{array}$ \\
\hline NONF5 & In our family business we employ non-family members to supplement our skills. \\
\hline \multicolumn{2}{|c|}{ NO OTHER FAMILY MEMBER INVOLVEMENT } \\
\hline OFAM4 & $\begin{array}{l}\text { Siblings not actively involved in the day-to-day operations of our family business } \\
\text { DO NOT interfere in business decision-making. }\end{array}$ \\
\hline OFAM5 & $\begin{array}{l}\text { Siblings not actively involved in the day-to-day operations of our family business } \\
\text { DO NOT become involved in disagreements between the siblings working in the } \\
\text { business. }\end{array}$ \\
\hline OFAM1 & $\begin{array}{l}\text { In our family business the spouses (life-partners) of sibling involved in the } \\
\text { business DO NOT interfere in business decision-making. }\end{array}$ \\
\hline OFAM2 & $\begin{array}{l}\text { In our family business the spouses (life-partners) of siblings involved in the } \\
\text { business DO NOT become involved in disagreements between siblings. }\end{array}$ \\
\hline \multicolumn{2}{|c|}{ NO PRESENT PARENT INVOLVEMENT } \\
\hline PARENT8 & $\begin{array}{l}\text { Our parents DO NOT (or did not if deceased) interfere in business decisions } \\
\text { made by my sibling(s) and I. }\end{array}$ \\
\hline PARENT6 & $\begin{array}{l}\text { Our parents DO NOT (or did not if deceased) get drawn into conflicts that arise } \\
\text { (arose) between my sibling(s) and I. }\end{array}$ \\
\hline PARENT7 & $\begin{array}{l}\text { Our parents ARE NOT (or were not if deceased) financially dependent on the } \\
\text { business. }\end{array}$ \\
\hline
\end{tabular}

